\title{
The Development of Interactive Media Based on Video Animation in the Use of a Total Station for Measurement Stake out the Building
}

\author{
Muhammad Bachrawi Luthfi ${ }^{1}$, Sunar Rochmadi ${ }^{2}$, Rihab Wit Daryono ${ }^{3}$, Rozan Pajri \\ Sandria Saputra ${ }^{4}$ \\ ${ }^{1,3}$ Technology and Vocational Education, Universitas Negeri Yogyakarta, Indonesia \\ ${ }^{2,4}$ Civil Engineering and Planning, Universitas Negeri Yogyakarta, Indonesia \\ mbluthfitanjung@gmail.com
}

\begin{abstract}
This study aims to: (1) develop the concept of instructional media based on total station animation video which is used to measure building stake out; (2) developing interactive media designs; (3) due diligence of interactive media; and (4) dissemination of interactive media. This research is a research and development which refers to the 4D model. Non-test instruments with fourscale answerchoices were used. The questionnaire was used in the expert validation process and the student's feasibility assessment. Data were analyzed quantitatively. The results of this research and development of instructional media conclude: (1) the concept of instructional media based on video animation of the total station is used to measure building stake out; (2) the initial media design consists of five main menus; (3) based on the assessment of instructional media by material experts it is categorized as "veryfeasible" with a percentage of $85.278 \%$ for the five aspects assessed; based on the evaluation of media experts, it is categorized as "very feasible" with a percentage of 90.409\% for the three aspects assessed; and based on users (students) the percentage is $81.306 \%$ with the category "very feasible"; (4) dissemination using two methods: offline and online.
\end{abstract}

Keywords

animated videos;

buildings; interactive

media; stake out; total

station

\section{Introduction}

Education has a very important position in the development of a country. Good and quality education can create competent and quality human resources. Education is a conscious and planned effort to create an atmosphere of learning and the learning process so that students actively develop their potential to have spiritual strength, self-control, personality, intelligence, noble character, and skills needed by themselves, society, nation and state (President of the Republic Indonesia, 2003). Education has an important role in developing the quality of human resources. 21st century education is a challenge for teachers as educators, and vocational high schools as educational institutions that produce graduates who are ready to work. The 21 st century skills curriculum is useful for students and teachers to prepare for future careers, where creativity and skills in using technology are the keys to success (Alismail \& McGuire, 2015).

Learning media is a means of delivering learning material that is more straightforward and interesting, resulting in a reciprocal relationship between teachers and students (Wahyu et al., 2017). The technological era that is currently developing has greatly influenced human life. Previously, manual activities have now shifted to technology-based, one of which is the implementation of the 2013 Curriculum (Akbarini et al., 2018). The 2013 curriculum 
instructs independent or online learning so that students can and are adjusted to seek information independently through the use of information technology and internet communication (Prastiyo \& Djohar, 2018). Students need supporting media in the lecture process, so that learning media is an important foundation in influencing student learning outcomes. The facts so far show that the majority of media used in universities are still unidirectional (Muslim et al., 2018).

According to Agus in Indrakasih (2019), the use of media is the systematic use of learning resources. The decision to try or use learning resources must pay attention to students' characteristics and learning objectives.

The use of media and technology and media by the teacher is additional support during teacher-centered teaching, for example a teacher might use an electronic whiteboard to display it as a bar graph when students estimate population growth over time. The teacher also uses diagrams to show the meaning of a sentence. The use of technology and media by their students can utilize technology and media in a series of ways to enhance learning, a guide to achieving certain goals. Utilizing student-centered activities, the teacher uses their time to examine and correct student problems, consult with the rest individually and teach one by one in small groups. (Sitorus, 2020)

Multimedia forces users to interact with the material. This interaction varies because the user can select the material to be studied, move the desired page, or can enter answers from the exercise then the computer responds by providing work and discussion through feedback (Ramadhani et al., 2019). Interactive learning media contribute to a positive effect in improving student learning outcomes (Rachmadtullah et al., 2018). This increases student motivation (Nadhya Noor \& Aisyah, 2018) and motivation shows a very beneficial effect on learning outcomes (Lin et al., 2017). The media to be developed is animation-based interactive learning media. Animated interactive learning media contains material about the understanding and explanation of the Beginner System which is made interactive so that students can choose the sub material they want to learn, and students are free to choose the desired menu options. The material is packaged as attractive as that, and is displayed in the form of text, images and animation. The use of multimedia in learning has proven to be a viable and viable alternative to traditional classrooms (Teoh \& Neo, 2007).

Animation can improve student understanding when used in a way that is in accordance with the cognitive theory of multimedia learning (Richard E. Mayer \& Roxana Moreno, 2002). Student responses in animation learning media are very positive (Sunarya \& Darmawiguna, 2014). It aims to make students easy and motivated to learn about the use of total station material to build reconnaissance measurements. Based on animated interactive learning media by utilizing technology, it is expected to increase students' understanding and motivation in Geomatics Practicum subjects, especially in the material of using total stations and measuring building poles. The results of each lesson can be categorized as feasible, valid, and good for use as a medium of learning in schools. Interactive animation-based learning media, especially multimedia, can provide benefits for teachers and students in learning activities (Priambodo \& Arifin, 2019).

One of the courses in Geometrics Practicum II in the Department of Civil Engineering and Planning UNY is Geometrics Practicum II or better known as land surveying. Soil geometry is part of geodesic science which studies the stages of measurement on the earth's surface and underground for various purposes, such as mapping, determining points, determining curvature and so on (Basuki, 2012). Along with the development of technology, new tools are used to take measurements with a higher level of precision and accuracy, one of 
which is the total station. Total Station is an electronic measuring instrument for angles and distances. Total Station makes measurements with the principle of emitting electromagnetic waves to get the measurement results.

\section{Research Method}

Certain products produced in this study are needs analysis and test the effectiveness of these products in order to function in the wider community, so research is needed to test the effectiveness of these products (Sugiyono, 2009). The research method used is Research and Development (R\&D). This research refers to the 4D model research and development model. According to (Lawhon, 1976) the 4D research and development model consists of four main stages, namely define, design, development, and disseminate. The research development procedure used refers to the $4 \mathrm{D}$ model. To simplify the research process, a research flow has been drawn up containing the stages of the research which can be seen in Figure 1.

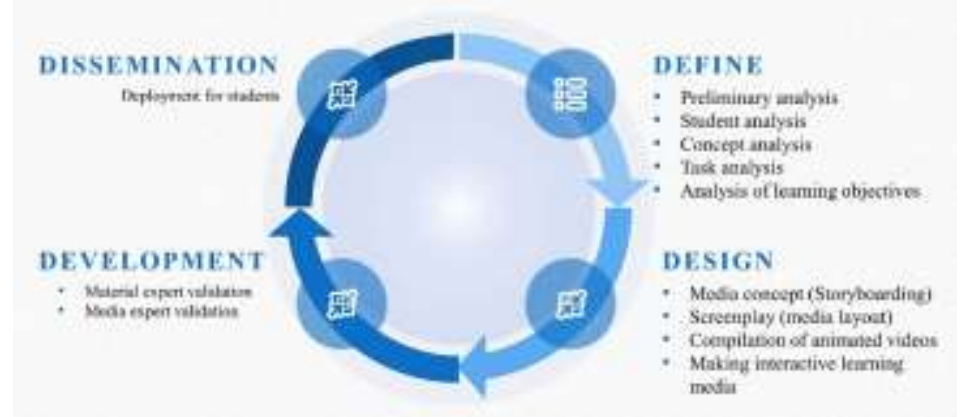

Figure 1. Research Model

Research subjects in the development of interactive media based on animated videos use a total station to measure buildings including material experts, media experts, and students of Civil Engineering and Planning Education, Yogyakarta State University. The data collection technique used in this study was a questionnaire. Packaged questionnaires were given to material experts and media experts. Before being given a questionnaire, it is validated first about the learning media that has been made.

The data analysis technique used is descriptive qualitative, which describes the learning media products designed after being implemented in the finished product and testing the feasibility of the product. The qualitative data obtained will then be converted into quantitative using a Likert scale. The development results were then validated by learning media experts (Herayanti et al, 2017). The answer for each instrument item that uses the Likert scale has a gradient from very positive to very negative (Sugiyono, 2015).

In this study, researchers took data using a questionnaire and using a positive Likert scale, with 4 levels because it reduces the likelihood of respondents answering moderate category answers if given a Likert scale with odd levels this applies to all assessments from experts and students. After obtaining the average percentage value, then proceed with the determination of the predicate of product quality based on the Rating Scale measurement scale. Data analysis techniques include data interpretation and data processing (Suyitno et al., 2018). The instrument in the form of a questionnaire was used to obtain the information or data needed according to the student's needs. Eligibility categories can be seen in Table 1 . 
Table 1. Instrument Item Score Rules

\begin{tabular}{ccc}
\hline Scale & Category & Percentage \\
\hline 5 & Very feasible & $81 \%-100 \%$ \\
4 & Worthy & $61 \%-80 \%$ \\
3 & Inadequate & $41 \%-60 \%$ \\
2 & Not feasible & $21 \%-40 \%$ \\
1 & Very Inadequate & $0 \%-20 \%$
\end{tabular}

\section{Discussion}

\subsection{Define Stage}

This stage is the initial stage carried out to underlie the development of this learning video. This stage aims to obtain information relevant to the needs of the product to be developed and identify various aspects that underlie the importance of developing instructional media products. The following are the development steps at the defining stage: (1) Front-end analysis, at the initial analysis stage the researcher conducts discussions with the supervisor so that the problems in the Geomatics Practicum II course are known. Based on the lecturer's explanation as educators, there are several problems in the learning process, namely: competencies that must be mastered a lot, limited practical tools, new material that must be mastered, limited learning time, the existing media is less interactive; (2) analysis of students, (3) analysis of concepts; (4) task analysis.

\subsection{Design Stage}

The second stage is designing the results of the analysis carried out from the define stage. Based on the data obtained from the define stage, it is obtained data that the media developed is a medium that can help students increase motivation and help understand both theory and practice in the Geomatics Practicum II course. So it is necessary to make interesting learning media in the form of animated videos. The following is the animation design process that the researchers did: (1) drafting the media concept; (2) main model creation; (3) creating animated scenes; (4) edit; (5) production.

\subsection{Development Stage}

The development of the instructional animation video begins with the opening then explains the learning objectives, increasing the total station for the reconnaissance menu, initial pegging, setting the target shot (prism relector), focusing on the target, the results of the target shot at the total station and the calculation result table. The development of animated videos is seen in Figure 2.

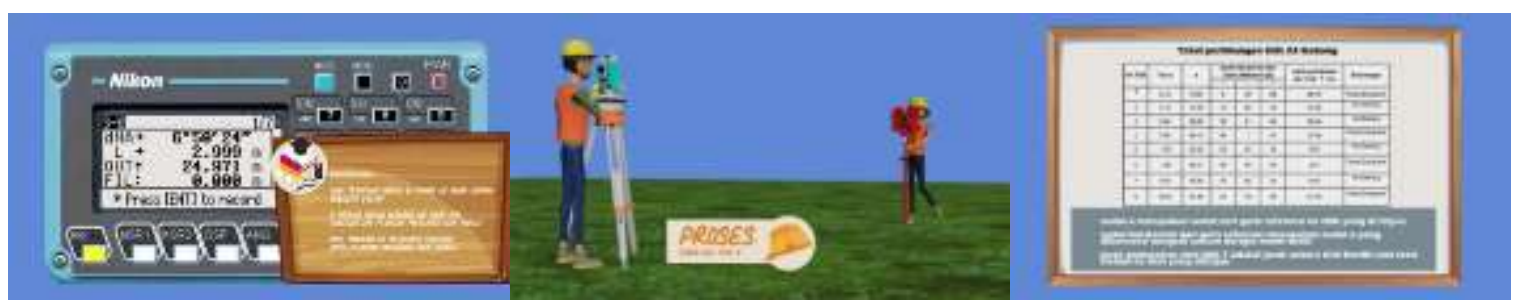

Figure 2. Display of the Learning Animation Video Using Total Station for Building Stake out Measurement 
The interactive learning media developed by researchers were designed and compiled using Power Point 2013 and iSpring Suit 8 software. This interactive media has been tested to be played on standard systems, namely OS Windows 8 and OS Windows 10 which includes Interactive Media Intro, main menu, Menu- Materials, Menu-Work Steps, Complete Videos, Menu-Download, Menu-Profile in Figure 3.

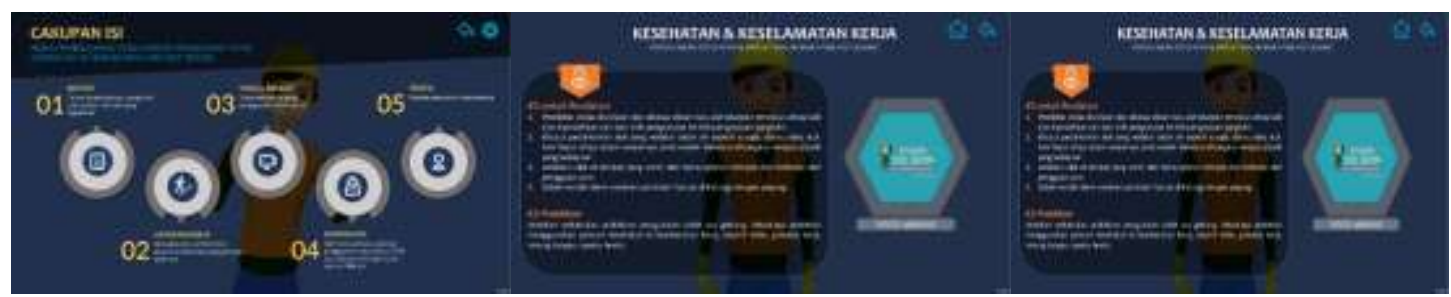

Figure 3. Display of Interactive Learning Media Based on Animation Video

Material validation was carried out to determine the feasibility of learning media in terms of the material. The material in the video is devoted to the steps of using the Nikon DTM-322 total station for building stake out measurements. Assessment by material expert lecturers is based on five aspects, namely learning objectives, learning materials, learning methods, learning resources, and learning activities. The five aspects were developed into 21 statement items. Before the learning video is validated, the statement item is validated first, if the instrument is suitable for use then the material is validated for the learning video. The results of media development validation based on material experts are presented in Table 2.

Table 2. Material Expert Validation Results

\begin{tabular}{clcccc}
\hline No. & \multicolumn{1}{c}{ Aspect } & $\sum$ Score & $\begin{array}{c}\text { SScore } \\
\text { Max }\end{array}$ & $\begin{array}{c}\text { Percentage } \\
(\%)\end{array}$ & Feasibility Level \\
\hline 1 & Learning objectives & 8 & 8 & 100,00 & Very feasible \\
2 & Learning materials & 35 & 36 & 97,222 & Very feasible \\
3 & Learning methods & 7 & 8 & 87,500 & Very feasible \\
4 & Learning resources & 8 & 8 & 100,00 & Very feasible \\
5 & Learning activities & 22 & 24 & 91,667 & Very feasible \\
Average & 16,0 & 16,8 & 95,278 & Very feasible \\
\hline
\end{tabular}

Source: The Data Processed in 2019

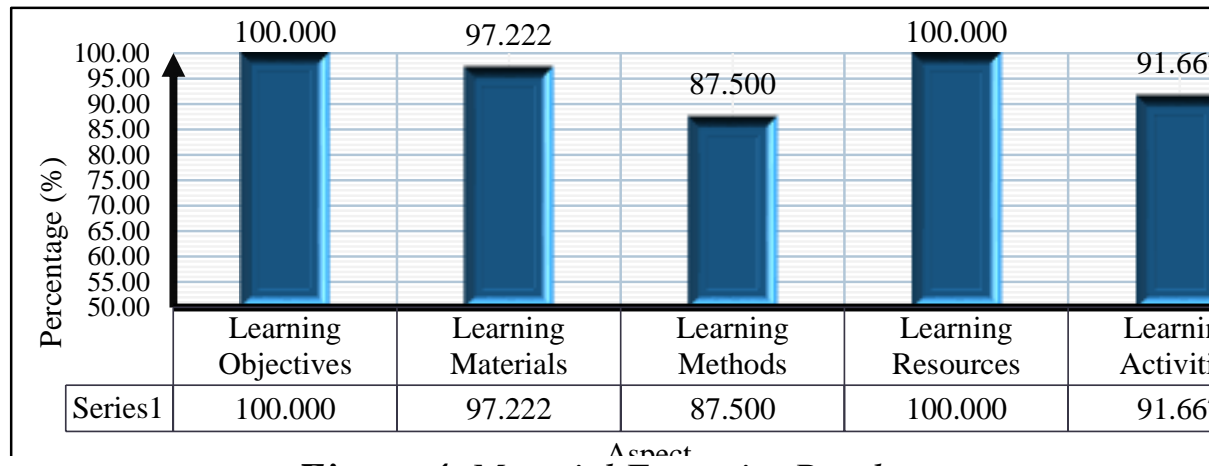

Figure 4. Material Expertise Results

The results of the calculation were obtained after the material expert lecturer assessed the five predetermined aspects to get the "very feasible" category after being converted according to the categorization of data processing. The maximum average value obtained was 16.80 and the average percentage obtained was $95.278 \%$. 
Media validation is carried out by media expert lecturers so that the feasibility of learning media is known. The assessment of media expert lecturers is based on three aspects, namely software engineering, learning design and visual communication. This aspect is developed into 26 statements which have been validated by the instrument first. After the instrument is declared feasible, then the learning media validation is carried out. The results of media development validation according to media experts can be seen in Table 3 .

Table 3.Media Expert Validation Results

\begin{tabular}{llcccc}
\hline No. & Aspect & $\sum$ Score & $\begin{array}{l}\sum \text { Score } \\
\text { Max }\end{array}$ & $\begin{array}{l}\text { Percentage } \\
(\%)\end{array}$ & $\begin{array}{l}\text { Feasibility } \\
\text { Level }\end{array}$ \\
\hline 1 & Software eng. Aspects & 31 & 32 & 96,87 & Very feasible \\
2 & Learning design aspects & 24 & 28 & 85,71 & Very feasible \\
3 & Visual communication aspects & 39 & 44 & 88,63 & Very feasible \\
Average & 31,3 & 34,67 & 90,40 & Very feasible \\
\hline
\end{tabular}

Source: The Data Processed in 2019

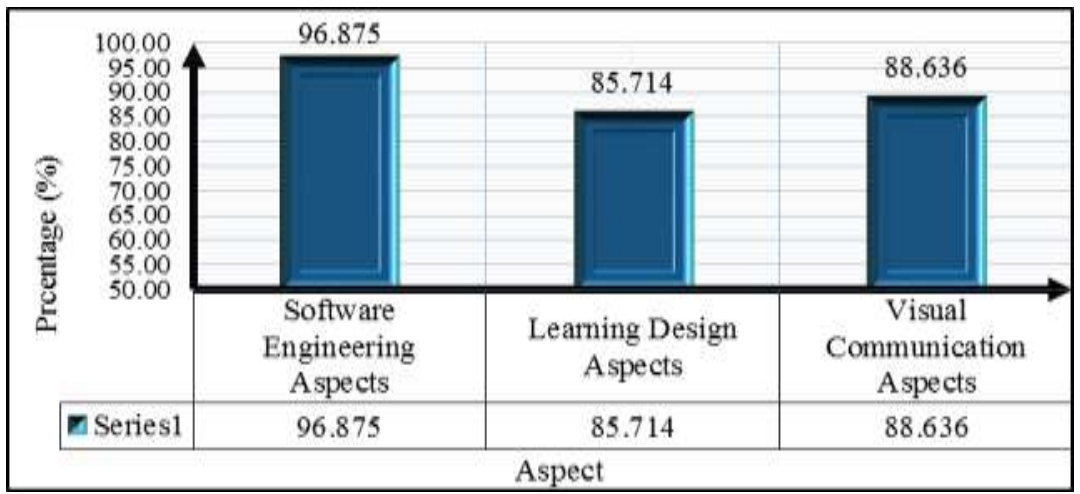

Figure 5. Media Expertise Results

The data obtained during media validation had a "very reasonable" level in all aspects after adjusting for the data processing cogogization. The average percentage of eligibility obtained is $90.409 \%$ so it is included in the "very feasible" category.

This learning media is based on needs analysis in the Department of Civil Engineering and Planning Education, Faculty of Engineering, Yogyakarta State University. The assessment of students is carried out after the media is validated by material expert lecturers and media expert lecturers. Data retrieval by users is done by distributing questionnaires conducted in the study. The questionnaire instrument was obtained from a combination of the material aspects of the instrument aspects and the media aspects. From these two aspects then developed into 20 statement items. The results of the feasibility test of animated video-based interactive learning media in the use of total stations for measuring building stake out by students are shown in Table 4.

Table 4. Media Assessment by Students

\begin{tabular}{clcccc}
\hline No & Aspect & $\sum$ Score & $\sum$ Score Maks & Percentge $(\%)$ & Feasibility Level \\
\hline 1 & Material & 973 & 1200 & 81,083 & Very feasible \\
2 & Media & 1174 & 1440 & 81,528 & Very feasible \\
Average & & 97,59 & 120,0 & 81,306 & Very feasible \\
\hline
\end{tabular}




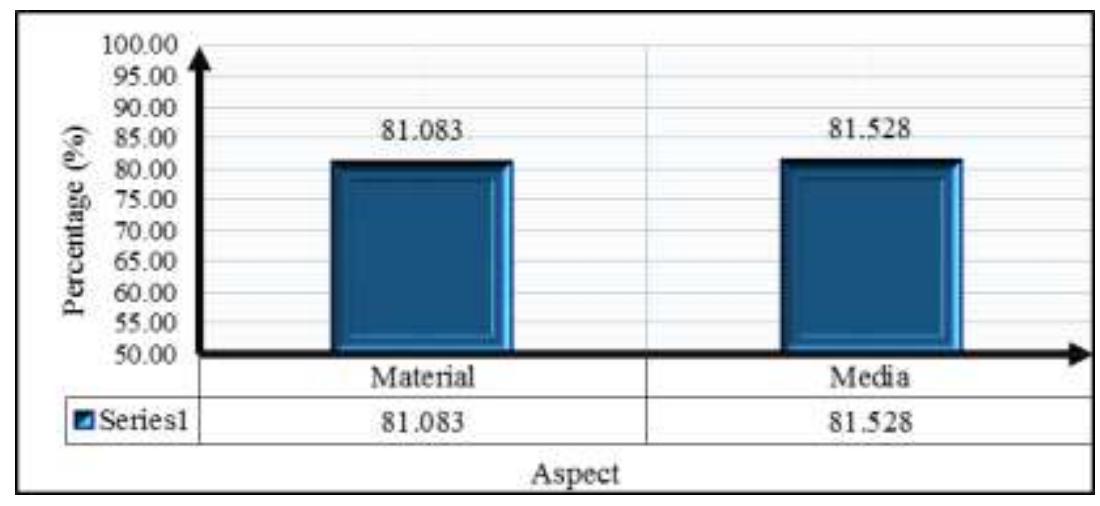

Figure 6. Media Assessment by Students

Researchers distributed questionnaires to students of the Department of Civil Engineering and Planning Education, Faculty of Engineering, Yogyakarta State University, who had attended Geometrics Practicum II courses and who had practiced material on building pile measurement. The number of respondents who filled out the questionnaire was 30 students. From the overall statements obtained from the assessment results obtained a total score of 2147. After calculating and converting the feasibility of obtaining an assessment of the learning media by the user with an average score of 81.306 . This score if converted into the "very feasible" category with an eligibility percentage of $81.306 \%$.

\subsection{Disseminate Stage}

This stage is the final stage of R\&D research. After the media goes through several stages of testing and assessment, namely from material expert lecturers, media expert lecturers, and users, the media can be published. Product publication is carried out in 2 ways, namely offline using a $\mathrm{CD}$ or flash disk (for file media only) and online through e-learning be-smart UNY (lecturers) and a YouTube channel with the link https://youtu.be/BqwYi9Jdwik and storage at Google Drive. A special publication is made for students of Civil Engineering and Planning Education, Faculty of Engineering, YSU who have taken or are currently taking Geomatics Practicum II courses. The socialization was carried out with the aim that the video-based learning media created could be widely used, not only for formal learning (in vocational high schools or universities), but also the wider community.

\section{Conclusion}

An animation video-based learning media is needed, especially with the material measuring the stake out of the building using a total station for students who will carry out Geomatics Practicum II. The animated video will be played on smartphones and computers. Validation of material experts obtained a score of 80 with a percentage value of $85,278 \%$ categorized as "very feasible". The validation of media experts obtained a score of 94 with a percentage of $90.409 \%$ included in the "very feasible" category. Assessment according to users (students) got a score of 2.147 with an average score of 81.306 getting a percentage of $81.306 \%$ eligibility for the category "very feasible".

Based on the results of research on the development of animation-based learning videos, the use of total stations to stake out the building has limitations in the study, such as the concept of the learning video presented is considered less smooth in its movement. This is due to the limited capabilities of the hardware used in the media making process. The initial design of the animation display in the learning video is still considered inaccurate because 
there are some animations that are not flexible to view, such as practical pictures in the video. The data analysis for the calculation of the pile building shown in the video is considered insufficient, so students must look at the guidelines first.

Learning media that have been made still have shortcomings so that improvements are needed for further product development, namely learning media that can be further developed by combining video with an application in the form of mp4 which can be accessed by users via cellphones. Suggestions that can be given by researchers after conducting research for further similar research are learning media that can contain some analysis material according to development needs. In further research, data transfer can be developed from the total station to Microsoft Excel and the distribution of learning media with an online system can be expanded again, not only uploaded to the YouTube channel.

\section{References}

Akbarini, N. R., Murtini, W., \& Rahmanto, A. N. (2018). The effect of Lectora inspire-based interactive learning media in vocational high school. Jurnal Pendidikan Vokasi, 8 (1): 78. https://doi.org/10.21831/jpv.v8i1.17970

Alismail, H. A., \& McGuire, P. (2015). 21 St Century Standards and Curriculum: Current Research and Practice. Journal of Education and Practice, 6 (6): 150-155. http://files.eric.ed.gov/fulltext/EJ1083656.pdf

Basuki, S. (2012). Ilmu Ukur Tanah. Gadjah Mada University Press.

Herayanti, L., Habibi, H., \& Fuaddunazmi, M. (2017). Pengembangan Media Pembelajaran Berbasis Moodle pada Matakuliah Fisika Dasar. Jurnal Cakrawala Pendidikan, 36 (2): 210-219. https://doi.org/10.21831/cp.v36i2.13077

Indrakasih, et al. (2019). Development of Basic Volleyball Learning Media Based on Web Learning Materials Towards KKNI at Universitas Negeri Medan. Budapest International Research and Critics in Linguistics and Education (BirLE)Journal. P. 139144.

Lawhon, D. (1976). Instructional development for training teachers of exceptional children: A sourcebook. Journal of School Psychology, 14 (1): 75. https://doi.org/10.1016/00224405(76)90066-2

Lin, M. H., Chen, H. C., \& Liu, K. S. (2017). A study of the effects of digital learning on learning motivation and learning outcome. Eurasia Journal of Mathematics, Science $\begin{array}{lllll}\text { and Technology } & \text { Education, } & 13 & \text { (7): }\end{array}$ https://doi.org/10.12973/eurasia.2017.00744a

Muslim, S., Gitama, N. P., Suprianto, B., Rahmadyanti, E., \& Kusumawati, N. (2018). Influence of learning media based on adobe flash professional to psychomotor domain learning outcomes on plc courses viewed from level of creative thinking student. Jurnal Pendidikan Vokasi, 8 (3): 267. https://doi.org/10.21831/jpv.v8i3.21552

Nadhya Noor, K. B., \& Aisyah, M. N. (2018). Development of Interactive Learning Media Based on Computer To Improve Student Learning Motivation. Jurnal Pendidikan Akuntansi Indonesia, 16 (2): https://doi.org/10.21831/jpai.v16i2.22054

Prastiyo, W., \& Djohar, A. (2018). Development of Youtube Integrated Google Classroom Based E-Learning Media for the Light-Weight Vehicle Engineering Vocational High School. Jurnal Pendidikan Vokasi, 8 (1): 53-66. http://journal.uny.ac.id/index.php/jpv

Presiden Republik Indonesia. (2003). Undang-Undang RI No 13 Tahun 2003 tentang Ketenagakerjaan. 1:34-35. 
Priambodo, A., \& Arifin, Z. (2019). Interactive Animation Based Learning Media on Starter $\begin{array}{lllll}\text { System Materials for Vocational Students. } 25 & \text { (2): 187-193. }\end{array}$ https://doi.org/10.21831/jptk.v25i2.20026

Rachmadtullah, R., Nadiroh, N., Sumantri, M. S., \& S, Z. M. (2018). Development of Interactive Learning Media on Civic Education Subjects in Elementary School. 251 (Acec): 293-296. https://doi.org/10.2991/acec-18.2018.67

Ramadhani, M., Gafari, M. O. F., \& Marice, M. (2019). Development of Interactive Learning Media on Material Writing Short Story Texts Based on Experience. Budapest International Research and Critics in Linguistics and Education (BirLE) Journal, 2 (1): 91-102. https://doi.org/10.33258/birle.v2i1.189

Richard E. Mayer \& Roxana Moreno. (2002). Animation as an Aid to Multimedia Learning. Springer Link, 14: 87-99.

Sitorus, L.,S.et al. (2020). Development of Powerpoint-Based Learning Media on Learning Aqeedah Morals. Budapest International Research and Critics in Linguistics and Education (BirLE) Journal. P. 958-964.

Sugiyono. (2009). Metode Penelitian Administrasi. Alfabeta.

Sugiyono. (2015). Metode Penelitian Pendidikan (Pendekatan Kuantitatif, Kualitatif, dan R \& D). Alfabeta.

Sunarya, I. M. G., \& Darmawiguna, I. G. M. (2014). Pengembangan ANIME (Animation Learning Media) Berbasis Multimedia untuk Pembelajaran Dasar Sistem Komputer Bahasan Instalasi Hardware. Sains Dan Teknologi, 3 (2): 378-391.

Suyitno, Widianto, I., \& Masrul, S. binti. (2018). Development of Learning Media for the Course of Two-Stroke Gasoline Motors to Improve Students' Learning Outcomes. Jurnal Pendidikan Teknologi dan Kejuruan, 24 (1): 83-90. https://doi.org/10.21831/jptk.v24i1.18008

Teoh, B., \& Neo, T.-K. (2007). Interactive Multimedia Learning: Students' Attitudes and Learning Impact in an Animation Course. Online Submission, 6 (4).

Wahyu, A., Wirawan, Dyah, C., Indrawati, S., \& Rahmanto, A. N. (2017). Pengembangan Media Pembelajaran Kearsipan Digital untuk Meningkatkan Hasil Belajar Siswa SMK Negeri 3 Surakarta. Jurnal Pendidikan Vokasi, 7 (1): 78-86.

http:/journal.uny.ac.id/index.php/jpv 